\title{
Treatment of Primary Vesicovaginal Fistula Repair with Bladder Mucosal Flap: A Report of Initial Case Series
}

\author{
Primer Vezikovajinal Fistülün Mesane Mukozal Flep Onarımı ile Tedavisi
}

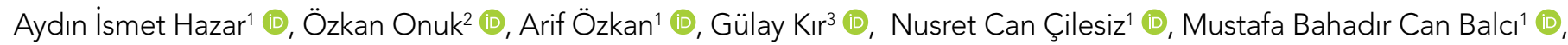 \\ Barış Nuhoğlu²
}

${ }^{1}$ Clinic of Urology, Health Scieces University Gaziosmanpaşa Taksim Training and Research Hospital, İstanbul, Turkey 2Department of Urology, Yeni Yüzyıl University, Gaziosmanpaşa Hospital, İstanbul, Turkey

${ }^{3}$ Intensive Care Unit, Koç University Hospital, İstanbul, Turkey

Cite this article as: Hazar Ai, Onuk Ö, Özkan A, Kır G, Çilesiz NC, Balcı MBC, et al. Treatment of Primary Vesicovaginal Fistula Repair with Bladder Mucosal Flap: A Report of Initial Case Series. JAREM 2018; 8(3): 177-81.

\begin{abstract}
Objective: Vesicovaginal fistula (VVF) is a disease that has been known for a long time. Most cases require surgical treatment. Although there are various techniques described for the management of WVF, none have been attributed as the gold standard of management. In this study, we describe our own technique using a transabdominal approach with a mucosal flap prepared from the bladder.

Methods: A total of 14 patients were operated between December 2011 and February 2016. The patients were scheduled for follow-up at the $1^{\text {st }}$, $3^{\text {rd }}, 6^{\text {th }}, 12^{\text {th }}$, and $24^{\text {th }}$ months, and outcomes were assessed in the following months. Treatment-associated complications and newly developing symptoms were recorded.

Results: Fourteen patients with a mean age of $28.5 \pm 5.58$ years were operated using the described technique. All patients had no recurrence of the fistula at the 24th month follow-up.

Conclusions: Removal of ischemic tissue and utilization of a well-vascularized flap are important. Sutures inserted in each layer should not overlap and be devoid of tension. Although the success rates of a simple WF is very high, the rates in patients with recurrent fistula or a fistula that developed because of radiotherapy or a malignancy are much lower. The technique that we employed is inspired from the hypospadias repair technique that involves a turn-over flap. We believe that having a short operation time, not using additional tissue for interpositioning, using the native bladder tissue for interpositioning, and a small incision to the bladder decrease the morbidities associated with surgery.
\end{abstract}

Keywords: Vesicovaginal fistula, fistula repair, new method, surgical repair

\section{ÖZ}

Amaç: Vezikovajinal fistül (VVF) uzun zamandır bilinen bir hastalıktır. Çoğu vaka cerrahi tedavi gerektirir. WVF'nin tedavisi için tanımlanan çeşitli teknikler olmasına rağmen bunlardan hiçbir yöntem altın standart olarak nitelendirilmemiştir. Bu çalışmada, kendi tekniğimizi, mesaneden hazırlanan mukozal flep ile transabdominal yaklaşımla tanımladık.

Yöntemler: Aralık 2011, Şubat 2016 arasında toplam 14 olgu opere edildi. Hastalar 1., 3., 6., 12. ve 24. aylarda kontrole çağııldı ve değerlendirildi. Tedaviye bağlı komplikasyonlar ve yeni gelişen semptomlar kaydedildi.

Bulgular: Tanımlanan teknikle ortalama yaşı 28,5 5,58 olan 14 hasta ameliyat edildi. 24. aydaki takipteki hiçbir hastada fistül nüksü görülmedi.

Sonuç: İskemik dokunun çıkarılması ve iyi vaskülarize bir flebin kullanılması önemlidir. Katlara konan sütürler, üst üste gelmemeli ve gergin olmamalıdır. Basit bir VVF'nin başarı oranları çok yüksek olmasına rağmen, tekrarlayan fistül veya radyoterapi veya malignite nedeniyle gelişen fistül hastalarındaki oranlar çok daha azdır. Kullandığımız teknik, bir kaydırma flebini içeren hipospadias onarım tekniğinden esinlenmiştir. İnterpozisyon için ek dokuyu kullanmama, nativ mesane dokusunun kullanımı ve mesaneye küçük bir insizyon yapılması operasyon süresinin azlığı ile ilişkili olarak cerrahiye bağlı morbiditelerin azaldığını düşünmekteyiz.

Anahtar Kelimeler: Vezikovajinal fistül, fistül onarımı, yeni teknik, cerrahi onarım

ORCID IDs of the authors: A.I.H. 0000-0001-5193-2340; Ö.O. 0000-0001-6497-0418; A.Ö. 0000-0003-6534-5403; G.K. 0000-0002-2487-359X; N.C.Ç. 00000003-2115-698X; M.B.C.B. 0000-0003-0395-1154. 


\section{INTRODUCTION}

Vesicovaginal fistula (VVF) is a disease that has been known for a long time (1). While prolonged labor is the major cause of this disease in developing countries, hysterectomies, obstetric trauma due to oncological surgeries, infectious and inflammatory diseases, and radiotherapy are the leading causes in developed countries $(2,3)$. In a study that included 1.000 patients, necrosis induced by increased pressure was proposed as the cause of the disease in cases of prolonged and difficult labor (4). It has been reported that the disease incidence is highest in Asia and sub-Saharan African regions (5). Conservative management of the disease comprises bladder drainage with a urethral catheter and/or endoscopic fulguration; however, these options have very low success rates (7\%-12.5\%). Most cases require surgical treatment with an abdominal, vaginal, or in some cases, a combined approach. Notably, the ideal surgical procedure for treatment is the one that the surgeon is most accustomed with (6). Although several techniques have been described, the search for an ideal technique with low morbidity and high success rates continues.

It has been proposed that patients with large fistulas that are close to the ureteral orifice or with unsuccessful previous interventions are best managed using the transabdominal approach. At least 3 months of delay of reconstructive surgery is recommended; however, in select cases, early intervention may also be a viable option (7). In this study, we describe our own technique using a transabdominal approach that includes repair of the VVF with a mucosal flap prepared from the bladder.

\section{METHODS}

Patients: A total of 14 cases, classified as Type 1 according to Waaldijk et al. (7) classification, were operated between December 2011 and February 2016, the study was designed in conformity with the Declaration of Helsinki. Gynecological surgery or delivery was the suspected cause of the fistulas. This technique was not utilized in complicated cases, such as previous history of radiotherapy and pelvic malignancies.

All patients underwent a detailed gynecological and urological evaluation. Vaginal examination, cystoscopy, and voiding cystourethrographies were performed for all patients. All patients provided signed informed consent prior to surgery. Routine urine and blood analysis was performed, and any patients with suspicion of infection provided a urine specimen for culture assessment. Any existing urinary tract infection was treated, and it was verified that patients had sterile urine prior to surgery. Fistula repair was performed at least 3 months after the initial diagnosis of the disease.

Fistula repair: Subsequent to surgical field preparation and antibiotic prophylaxis with $2^{\text {nd }}$ generation cephalosporins, a Phanenstiel incision was made to approach the bladder. The bladder was opened with a longitudinal incision, and the fistula opening from the interior surface of the bladder was identified and the diameter of the defect was measured. Subsequent to fistula identification, 4 Charrier ureteral catheters were introduced in both ureters. This was followed by removal of the whole fistula tract down to the vagina together with the neighboring healthy tissue (approximately $0.5 \mathrm{~cm}$ ) (Figure 1).

After removal of the fistula tract, the vaginal wall was sutured with $2 / 0$ sutures from the abdominal exposure gained. The bladder wall was closed with $3 / 0$ polyglat in sutures (Figure 2). At this stage of the operation, the internal surface of the bladder defect was closed. This was conducted by preparing a flap from the neighboring mucosal area of the defect visualize. The prepared flap was inverted on the defect and sutured to the accompanying parts of the mucosal defect. For this purpose, 4/0 sutures were used. In summary, the approach allowed a 4-layer closure (Figure 3-6).

Completion of the fistula repair was followed by removal of the ureteral catheters and closure of the bladder incision with an $18 \mathrm{~F}$ silicone Foley catheter left in place. A drain was placed and removed on $2.5 \pm 0.7$. Urethral catheters were removed main postoperative day 10 , and all patients were externalized within $2.78 \pm 0.69$ days. All patients were scheduled for followup on the $1^{\text {st }}, 3^{\text {rd }}, 6^{\text {th }}, 12^{\text {th }}$, and $24^{\text {th }}$ months.

Clinical data collected: All demographic data of patients were collected in addition to their clinical history. Treatment outcomes were assessed on the $1^{\text {st }}, 3^{\text {rd }}, 6^{\text {th }}, 12^{\text {th }}$, and $24^{\text {th }}$ postoperative months. Treatment-associated complications and newly developing urinary symptoms were also recorded.

\section{RESULTS}

Fourteen patients with a mean age of $28.5 \pm 5.58$ years were operated using the described technique. Demographic data, fistula diameter and location, and etiological reason of the fistula are summarized in Table 1. The mean operation time was 65.92 $\pm 8.71 \mathrm{~min}$ (Table2). The mean follow-up time was 9-24 months. Postoperative dyspareunia developed in one patient, which was not resolved at the $6^{\text {th }}$ month checkup. No patient had urgency, urinary incontinence, or any other associated urinary tract symptom during follow-up. All patients at the $6^{\text {th }}-24^{\text {th }}$ month follow-up had no recurrence of the fistula. No patient was lost to follow-up.

\section{DISCUSSION}

The aim of VVF management is to restore the physiological urine storage and voiding function and avoid the diverted urine flow. In a study it describes successful closure of VVF by bladder drainage alone, although it is generally true that some form of surgical repair is necessary for successful closure of $V V F(8)$.

Although there are various techniques described for the management of VVF, none one have been attributed as the gold standard for management. Fistulas with a diameter of 2 to 3 $\mathrm{mm}$ and newly developed fistulas can be managed with conservative options, including placement of a urinary catheter 
Table1. Patients' distribution according to fistula diameter, localization, and etiology

\begin{tabular}{|l|c|c|c|c|}
\hline Patient & Age & Diameter $(\mathbf{c m})$ & Localization & Etiology \\
\hline 1 & 24 & 1.5 & Supratrigonal & Vaginal Birth \\
\hline 2 & 23 & 1.7 & Trigonal & Vaginal Birth \\
\hline 3 & 31 & 2 & Supratrigonal & Vaginal Birth \\
\hline 4 & 34 & 3 & Supratrigonal & Vaginal Birth \\
\hline 5 & 32 & 2.4 & Supratrigonal & Vaginal Birth \\
\hline 6 & 27 & 2.2 & Trigonal & Vaginal Birth \\
\hline 7 & 41 & 2.8 & Supratrigonal & Vaginal Hysterectomy \\
\hline 8 & 26 & 2 & Supratrigonal & Vaginal Birth \\
\hline 9 & 26 & 2 & Supratrigonal & Vaginal Birth \\
\hline 10 & 30 & 2 & Trigonal & Vaginal Birth \\
\hline 11 & 28 & 2.5 & Supratrigonal & Vaginal Birth \\
\hline 12 & 34 & 2.6 & Trigonal & Vaginal Birth \\
\hline 13 & 23 & 1.8 & Supratrigonal & Vaginal Birth \\
\hline 14 & 20 & 1.5 & Supratrigonal & Vaginal Birth \\
\hline
\end{tabular}

\section{Table 2. Information about the procedure}

\begin{tabular}{|l|c|c|}
\hline Patient & Operation Time (min) & Discharge Time (day) \\
\hline 1 & 60 & 3 \\
\hline 2 & 75 & 3 \\
\hline 3 & 80 & 4 \\
\hline 4 & 70 & 2 \\
\hline 5 & 85 & 2 \\
\hline 6 & 65 & 3 \\
\hline 7 & 65 & 3 \\
\hline 8 & 58 & 3 \\
\hline 9 & 60 & 3 \\
\hline 10 & 65 & 2 \\
\hline 11 & 55 & 4 \\
\hline 12 & 60 & 3 \\
\hline 13 & 60 & 2 \\
\hline 14 & 65 & 2 \\
\hline
\end{tabular}

and anticholinergic administration. Other fistulas with a larger diameter and fistulas not responding to conservative management option at least after 3 months are surgically managed (9).

Various surgical techniques have been described depending on the size, site, and etiology or complexity of the fistulas, including abdominal and vaginal approach strategies (10). Success rates are reported to be as high as $90 \%(11$,
12). To achieve the desired successful outcomes, some principals have been defined for the management of VVF. Removal of ischemic tissue and utilization of a healthy and well-vascularized flap are important. Sutures inserted in each layer should not overlap and be devoid of tension (13).

The bladder mucosal graft has been used in urethro- plasties for many years. In 1985, in a study reported good results for VVF treatment using a bladder mucosal autograft in a canine model and in a woman with recurrent multiple VVF. In the same year at another study they reported successful closure of VVF using bladder mucosa (14).

Repair of supratrigonal fistulas using the O'Connor technique is regarded as one of the standard procedures (15). Excision of the fistula tract allowing a tight free closure can be achieved by mobilization of the bladder and vagina using a retroperitoneal approach $(16,17)$. The bladder anterior wall is opened with a long longitudinal incision. Subsequent to closure of the vaginal defect and prior to closure of the bladder defect, local well-vascularized tissue is placed between the two layers. The flap that is placed between the layers can be retrieved from the omentum or surrounding fatty tissue in the pelvis; however, the omentum is most frequently used.

In our study, the technique we utilized is inspired from the hypospadias repair technique, which involves a turn-over flap. This approach does not require the placement of a flap between the bladder and vagina as described in the O'Connor technique. This allows us to work out of the peritoneum for harvesting an omental flap and avoiding associated complications, such as ileus and peritonitis. We believe that having a short operation time, not using additional tissue for interpo- 


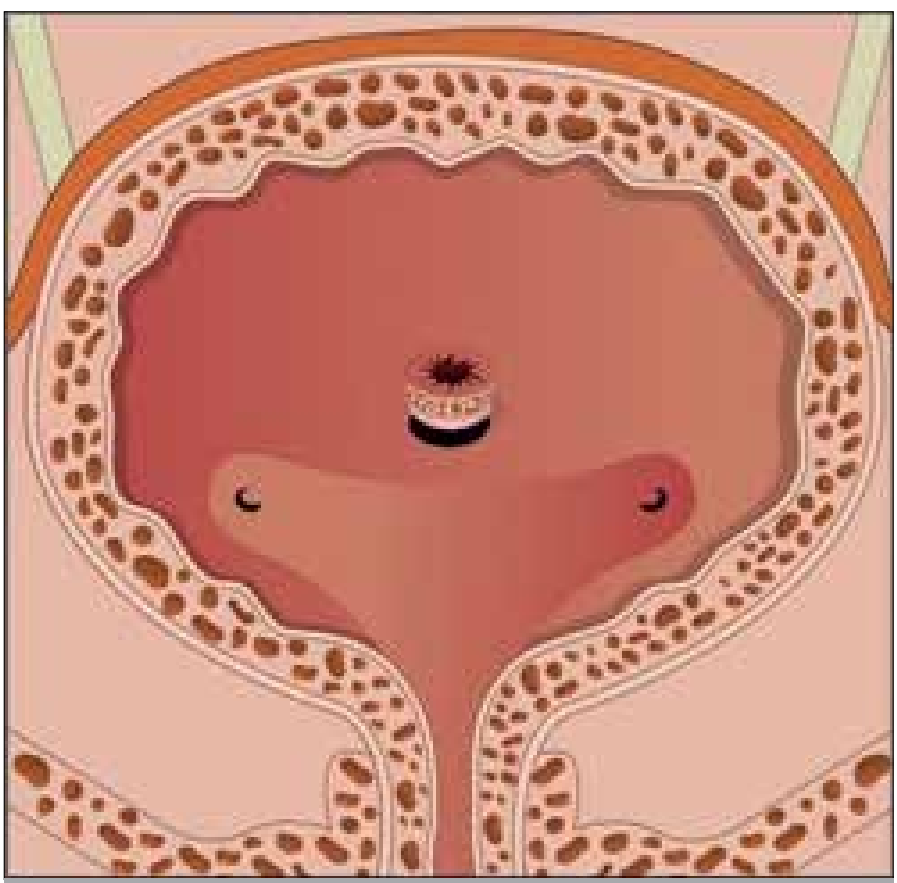

Figure 1. Identification of the fistula and removal of the fistula tract

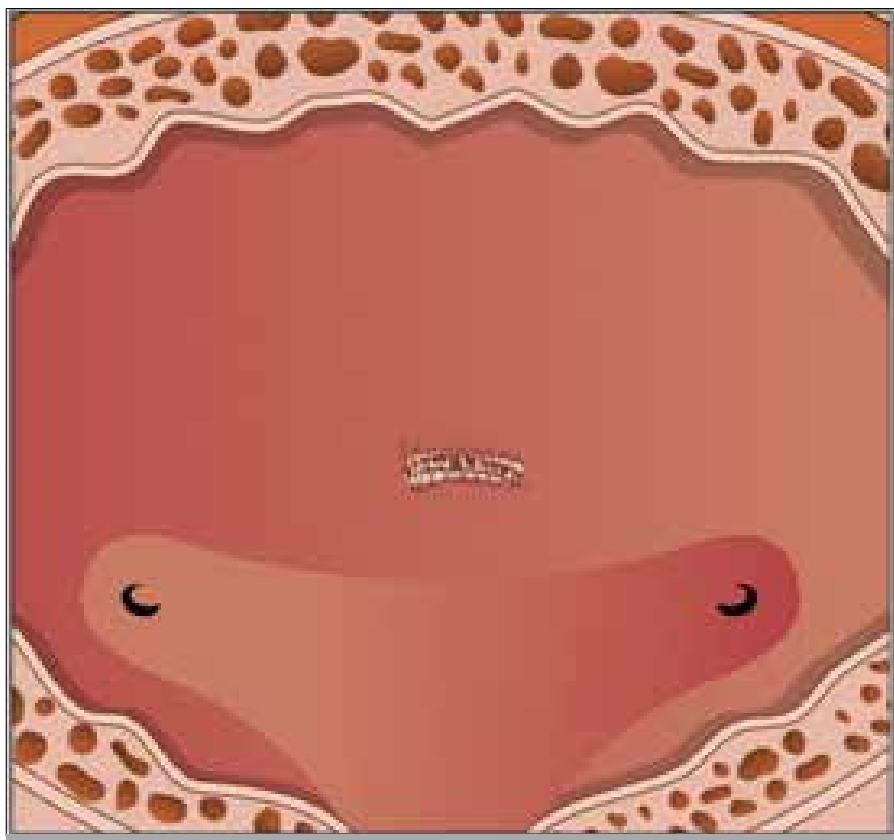

Figure 2. Closure of the vaginal defect and the external bladder wall

sitioning, using the native bladder tissue for interpositioning, and a small incision to the bladder decreases the morbidities associated with surgery.

Similar to the technique presented in a recent research, 20 cases with VVF were surgically repaired, and a flap was constructed from the medial side of the bladder to cover its defect. This flap was also supported by the hemostatic matrices. Patients were followed up for 2 years and no recurrences were recorded. However, five patients reported mild-to-moderate levels of dyspareunia (17).

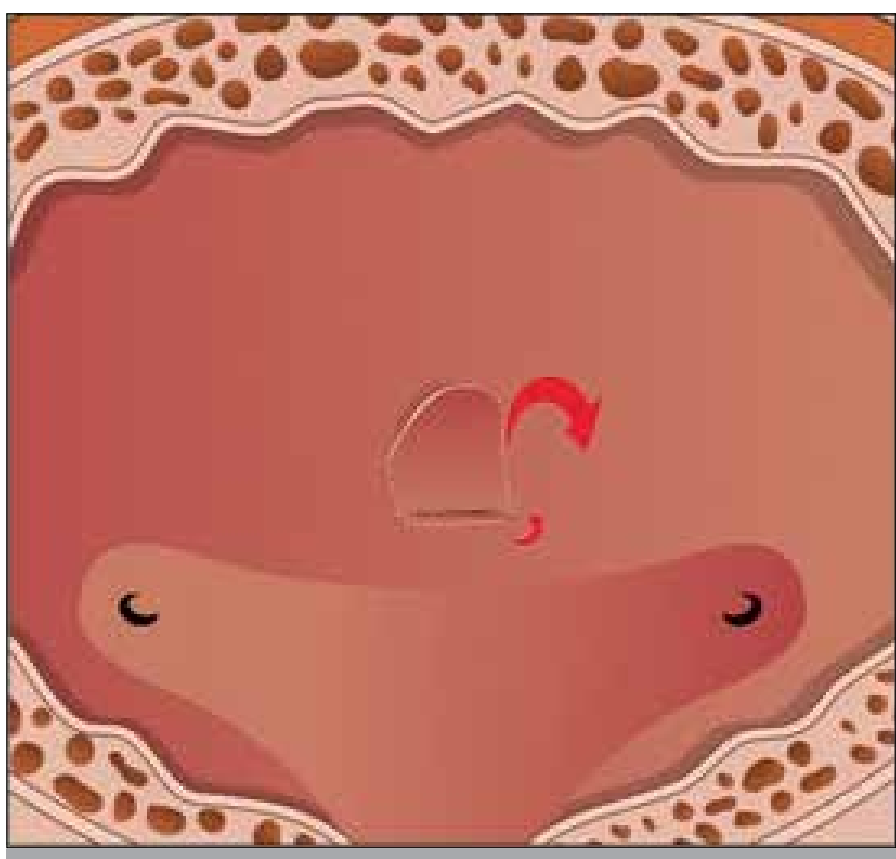

Figure 3. Repair of the flap next to the bladder mucosa defect and inversion of the flap over the defect

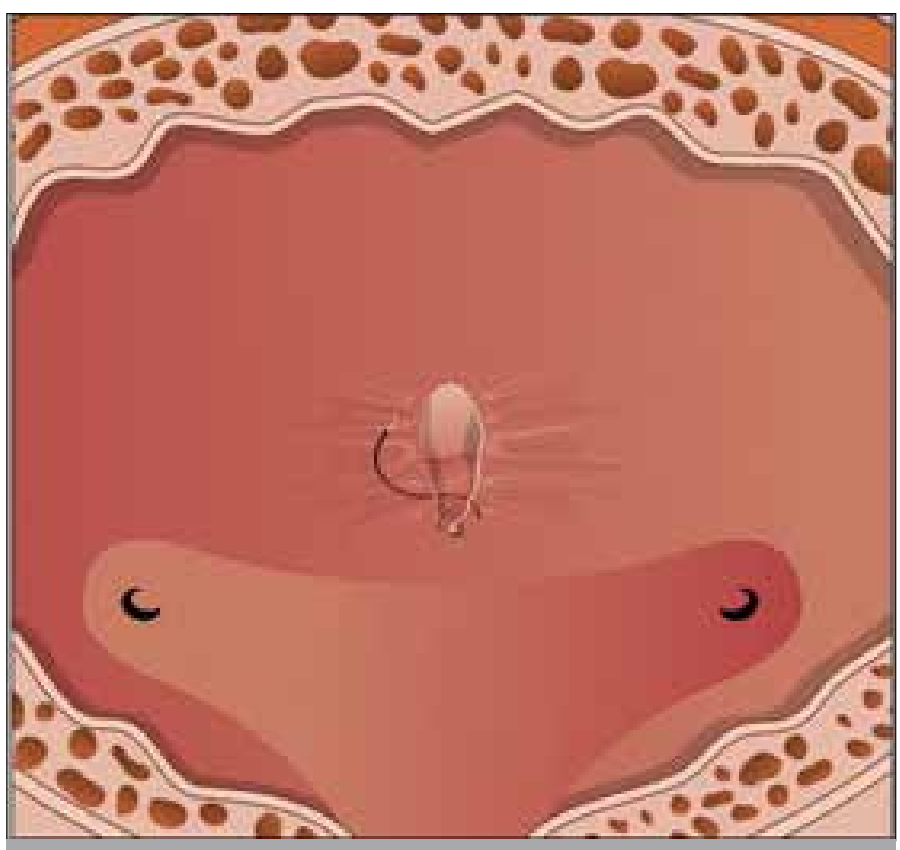

Figure 4. Steps of closure of the defect with the bladder mucosa flap and the final view of closure of the fistula with flap prepared from native bladder mucosa

\section{CONCLUSION}

This study, which was conducted with a limited number of patients, indicates that VVF repair can be an efficient and reliable method when executed with a technique similar to the overflap technique, which is frequently preferred for hypospadias fistula repair. Future randomized prospective studies conducted with a higher number of participants should provide more conclusive results. 


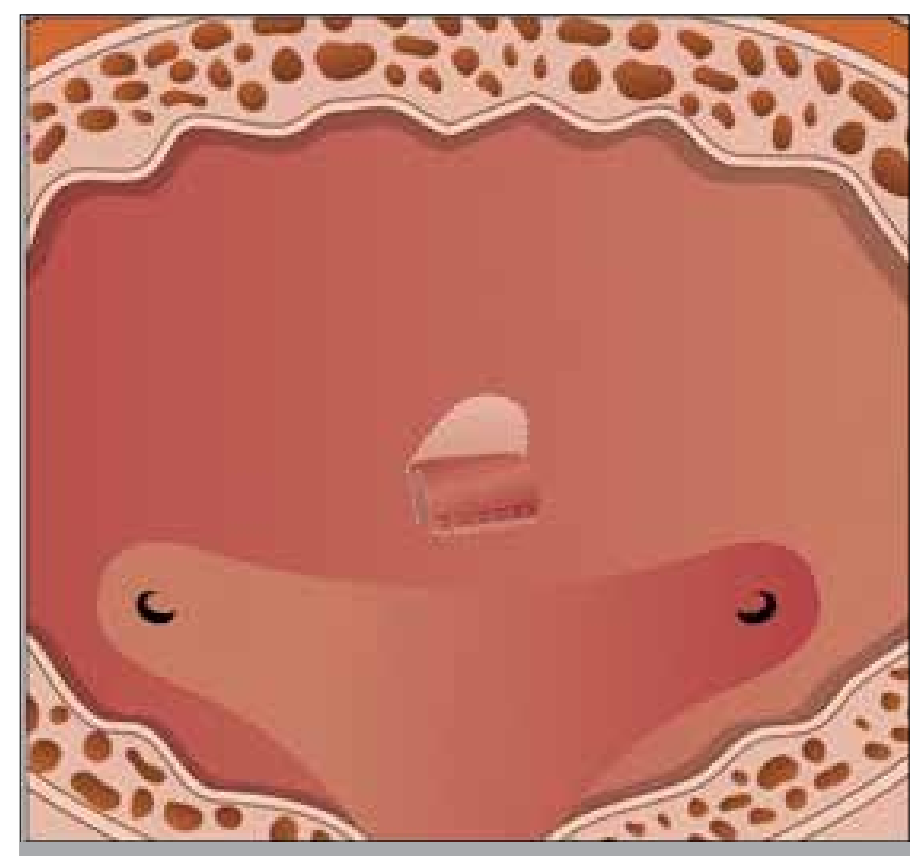

Figure 5. Steps of closure of the defect with the bladder mucosa flap and the final view of closure of the fistula with flap prepared from native bladder mucosa

Ethics Committee Approval: Authors declared that the research was conducted according to the principles of the World Medical Association Declaration of Helsinki "Ethical Principles for Medical Research Involving Human Subjects", (amended in October 2013).

Informed Consent: Written informed consent was obtained from patients who participated in this study.

Peer-review: Externally peer-reviewed.

Author Contributions: Concept - B.N., M.B.C.B.; Design - A.Ö.; Supervision - G.K.; Resources - A.I.H.; Data Collection and/or Processing - N.C.Ç.; Analysis and/or Interpretation - Ö.O.; Literature Search - G.K.; Writing Manuscript A.Ö.; Critical Review - B.N.

Conflict of Interest: The authors have no conflict of interest to declare.

Financial Disclosure: The authors declared that this study has received no financial support.

Etik Komite Onayı: Yazarlar çalışmanın World Medical Association Declaration of Helsinki "Ethical Principles for Medical Research Involving Human Subjects", (amended in October 2013) prensiplerine uygun olarak yapıldığını beyan etmişlerdir.

Hasta Onamı: Çalışmaya katılan hastalardan yazılı onam alınmıştır.

Hakem Değerlendirmesi: Dış bağımsız.

Yazar Katkıları: Fikir - B.N., M.B.C.B.; Tasarım - A.Ö.; Denetleme - G.K.; Kaynaklar - A.I.H.; VeriToplanmasıve/veyalşlemesi- N.C.Ç.; Analizve/veyaYorum- Ö.O.; LiteratürTaraması - G.K.; Yazıyı Yazan - A.Ö.; Eleştirellinceleme - B.N.

Çıkar Çatışması: Yazarların beyan edecek çıkar çatışması yoktur.

Finansal Destek: Yazarlar bu çalışma için finansal destek almadıklarını beyan etmiştir.

\section{REFERENCES}

1. Farahat YA, Elbendary MA, Elgamal OM, et al. Application of small intestinal submucosa graft for repair of complicated vesicovaginal fistula: A pilot study. J Urol 2012; 188: 861-4. [CrossRef]

2. Wadie BS, Kamal MM. Repair of vesicovaginal fistula: Single-centre experience and analysis of outcome predictors. Arab J Urol 2011; 9: 135-8. [CrossRef]

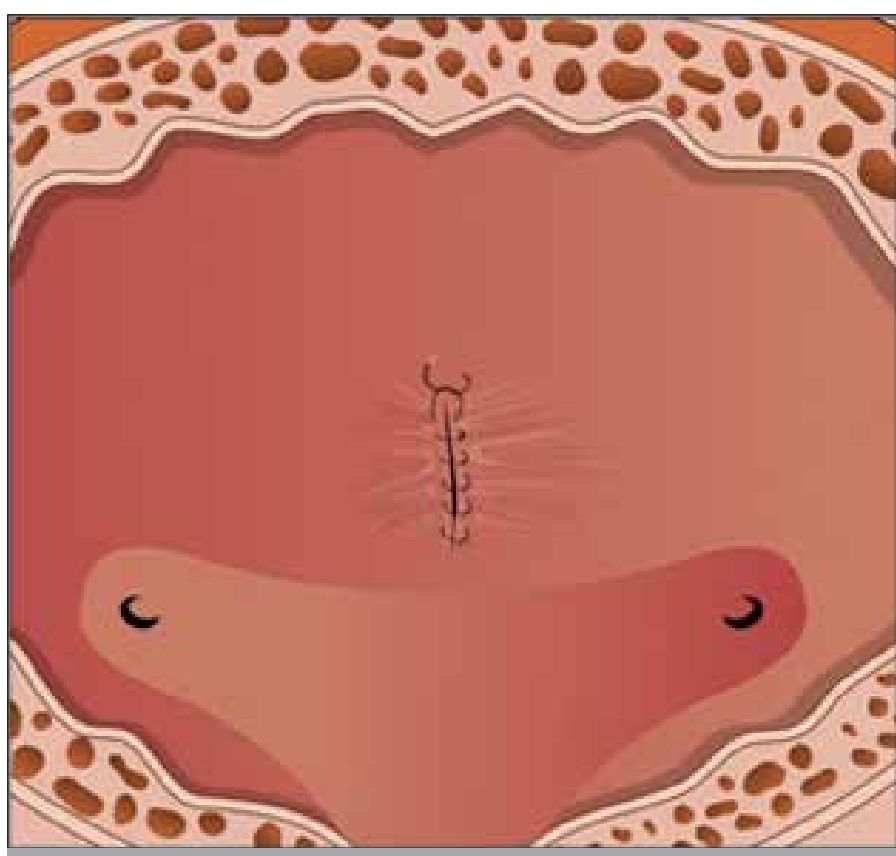

Figure 6. Steps of closure of the defect with the bladder mucosa flap and the final view of closure of the fistula with flap prepared from native bladder mucosa

3. Goodwin WE, Scardino PT. Vesicovaginal and ureterovaginal fistulas: a summary of 25 years of experience. J Urol 1980; 123: 370-4. [CrossRef]

4. Schlunt EK, Kavalier E, Rodriguez L, Rosenblum N, Raz S. Ten-year experience with transvaginal vesicovaginal fistula repair using tissue interposition. J Urol 2003; 169: 1033-6. [CrossRef]

5. De Ridder D: Vesicovaginal fistula: a major healthcare problem. CurrOpinUrol 2009; 19: 358-61. [CrossRef]

6. Rovner ES, Urinary tract fistulae. In: McDougal W, Wein A, Kavoussi L, Novick A, Partin A, Peters C, et al. editors. Campbell-Walsh Urology. $10^{\text {th }}$ ed. Philadelphia: Elsevier-Saunders; 2011.p.2223-261.

7. Waaldijk K. Surgical classification of obstetric fistulas. Int J GynecolObstet 1995; 49: 161-3. [CrossRef]

8. Vyas N, Nandi PR, Mahmood M, Tandon V, Dwivedi US, Singh PB.Bladder mucosal autografts for repair of vesicovaginal fistula. BJOG 2005; 112: 112-4. [CrossRef]

9. Davits RJ, Miranda SI. Conservative treatment of vesicovaginal fistulas by bladder drainage alone. Br J Urol1991; 68:155-6. [CrossRef]

10. Mehmood A, Alvi MS, Rana S, Raziq S, Siddiq L, Shah MY. Vesicovaginal fistula: interposition flap, a key to success. J Ayub Med Coll Abbottabad 2009; 21:29-31.

11. Cheng EY and Kropp BP: Urologic tissue engineering with small-intestinal submucosa: potential clinical applications. World J Urol 2000; 18:26-30. [CrossRef]

12. Farahat YA, Elbahnasy AM, El-Gamal OM, Ramadan AR, El-Abd SA, Taha MR. Endoscopic urethroplasty using small intestinal submucosal patch in cases of recurrent urethral stricture: a preliminary study. J Endourol 2009; 23:2001-5. [CrossRef]

13. Hong HM, Lee JW, Han DY, JeongHJ. Vesicovaginal fistula repair using a transurethral pointed electrode. Int Neurourol J 2010; 14: 65-8. [CrossRef]

14. Sharifi-Aghdas F, Ghaderian N, Payvand A. Free bladder mucosal autograft in the treatment of complicated vesicovaginal fistula. BJU Int 2002;89; 54-6. [CrossRef]

15. Atala A. Tissue engineering, stem cells and cloning for the regeneration of urologic organs. Clin Plast Surg 2003; 30: 649-67. [CrossRef]

16. Dalela D, Ranjan P, Sankhwar PL, Sankhwar SN, Naja V, Goel A. Supratrigonal WF repair by modified $\mathrm{O}^{\prime}$ Connor's technique: an experience of 26 cases. Eur Urol 2006; 49: 551-6. [CrossRef]

17. Berglund RK, Vasavada S, Angermeier K, Rackley R. Buccal mucosa graft urethroplasty for recurrent stricture of female urethra. Urology 2006; 67:1069-71. [CrossRef] 